\title{
Treatment and Prevention of Common Complications of Chronic Kidney Disease
}

\author{
Sheikh Salahuddin Ahmed ${ }^{1}$, Md. Aminul Haque Khan ${ }^{2}$, Tarafdar Runa Laila ${ }^{3}$ \\ Received: August 26, 2013 Accepted: October 9, 2013
}

\begin{abstract}
Chronic kidney disease (CKD) is a worldwide public health problem with an increasing incidence and prevalence. Outcomes of CKD include not only complications of decreased kidney function and cardiovascular disease but also kidney failure causing increased morbidity and mortality. Unfortunately, CKD is often undetected and undertreated because of its insidious onset, variable progression, and length of time to overt kidney failure. Diabetes is now the leading cause of CKD requiring renal replacement therapy in many parts of the world, and its prevalence is increasing disproportionately in the developing countries. This review article outlines the current recommendations from various clinical guidelines and research studies for treatment, prevention and delaying the progression of both CKD and its common complications such as hypertension, anemia, renal osteodystrophy, electrolyte and acid-base imbalance, and hyperlipidemia. Recommendations for nutrition in CKD and measures adopted for early diabetic kidney disease to prevent further progression have also been reviewed. There is strong evidence that early detection and management of CKD can prevent or reduce disease progression, decrease complications and improve outcomes. Evidence supports that achieving optimal glucose control, blood pressure, reduction in albuminuria with a multifactorial intervention slows the progression of CKD. Angiotensin-converting enzyme inhibitors and angiotensin-II receptor antagonists are most effective because of their unique ability to decrease proteinuria, a factor important for the progression of CKD.
\end{abstract}

Key words: Chronic kidney disease, Diabetic kidney disease, End stage renal disease, Proteinuria, Microalbuminuria, Macroalbuminuria

J Enam Med Col 2014; 4(1): 45-55

\section{Introduction}

Chronic kidney disease is a major global public health problem equally affecting the people of developed countries as well as developing countries. It is recognized as a risk factor for cardiovascular disease (CVD), hypertension, renal osteodystrophy, anemia and malnutrition. ${ }^{1}$ When advanced, it also carries a higher risk of mortality. ${ }^{2}$ As kidney function deteriorates, patients develop complications related to fluid overload, electrolyte and acid-base imbalances, and the build-up of nitrogenous waste products. To survive, some patients eventually need hemodialysis or kidney transplantation. But treatment with dialysis or transplantation is very expensive and difficult for peoples of countries like Bangladesh. CKD is frequently unrecognized and is often undertreated. Early recognition and intervention are essential to slow disease progression, maintain quality of life and improve outcome.

It is important to identify the cause of CKD so that specific therapy can be instituted. Causes of CKD include glomerulonephritis, diabetes mellitus (DM), hypertension, urinary tract infection, urinary tract

1. Professor, Department of Medicine, Bangladesh Institute of Health Sciences, Dhaka

2. Professor, Department of Biochemistry, Enam Medical College, Savar, Dhaka

3. Assistant Professor, Department of Obstetrics \& Gynecology, Bangabandhu Sheikh Mujib Medical University, Dhaka Correspondence Sheikh Salahuddin Ahmed, Email: drsksalahahmed@yahoo.com 
obstruction, tubulo-interstitial nephropathy and infiltrative diseases. Studies in South Asian countries including Bangladesh have shown glomerulonephritis to be the most common cause of end stage renal disease (ESRD) followed by $D_{M} .^{3-5}$ The most frequent cause of CKD in North America and Europe is DM followed by hypertension. ${ }^{6}$ Diabetes mellitus is now becoming increasingly prevalent in developing countries, perhaps due to change in dietary habits, diminished physical activity and weight gain. ${ }^{6}$ Therefore, DM is now the leading cause of ESRD requiring renal replacement therapy (RRT) in many parts of the world, and its prevalence is increasing disproportionately in the developing world. ${ }^{6}$ Patients with newly diagnosed CKD often also present with hypertension. When no overt evidence for a primary glomerular or tubulointerstitial kidney disease process is present, CKD is often attributed to hypertension. ${ }^{6}$ The incidence of ESRD in our country is not known, but would be much higher than that in developed countries because of high incidence of infection and environmental pollution as well as increasing prevalence of DM.

This article critically reviews the current recommendations and therapeutic strategies published in recent journals and various clinical guidelines for treatment and preventing or delaying the progression of CKD and it's common complications.

\section{Definition of chronic kidney disease}

The National Kidney Foundation (NKF), an organization in United States defines CKD as either kidney damage or decreased kidney function for 3 months or more. ${ }^{7}$ The definition of CKD is the same regardless of age, sex and race. This definition is widely accepted and has been adopted in various clinical guidelines. ${ }^{2,8-13}$ Decreased kidney function means a glomerular filtration rate (GFR) of less than $60 \mathrm{~mL}$ per minute per $1.73 \mathrm{~m}^{2}$ body surface area. ${ }^{7}$ A GFR rate of more than $60 \mathrm{~mL} / \mathrm{min} / 1.73 \mathrm{~m}^{2}$ is considered abnormal if it is accompanied by documented evidence of kidney damage. The principal marker of kidney damage is the presence of persistent protein in urine. Other evidence of kidney damage includes abnormalities in urine sediment, blood and urine biochemistry, or abnormal findings in imaging studies. ${ }^{7}$ CKD can also be defined by the presence of urinary albumin in an excretion rate higher than $300 \mathrm{mg}$ per 24 hours (macroalbuminuria) or urinary protein excretion $0.5 \mathrm{~g} / 24$ hours or more (significant proteinuria). ${ }^{7-9,14}$ However, microalbuminuria or 24-hour urinary albumin excretion in the range of 30 to $300 \mathrm{mg}$ indicates the early stage of kidney disease in DM. ${ }^{15}$

\section{Glomerular filtration rate (GFR)}

The GFR is the best measure of overall kidney function. ${ }^{7}$ The normal level of GFR varies according to age, sex, and body size. In healthy young adult of 30 years or younger, the normal GFR is approximately 125 $\mathrm{mL} / \mathrm{min}$ per $1.73 \mathrm{~m}^{2}$ and declines by approximately 1 $\mathrm{mL} / \mathrm{min}$ per $1.73 \mathrm{~m}^{2}$ per year thereafter. ${ }^{7}$ Estimation of the GFR no longer requires a 24-hour urine collection for creatinine clearance; it can be accomplished with similar accuracy using mathematic formulas. Most commonly used formulas are the Modification of Diet in Renal Disease (MDRD) equation and the CockcroftGault equation (Table I). Many laboratories now report an estimated GFR (eGFR), using one of these equations. The MDRD has the advantage of being more accurate than the Cockcroft-Gault in persons with a GFR less than $90 \mathrm{~mL} / \mathrm{min}$ per $1.73 \mathrm{~m}^{2}$ and takes race into consideration. ${ }^{7,16,17}$ At GFR below $60 \mathrm{~mL} / \mathrm{min}$, the prevalence of complications of CKD increases. ${ }^{18-20}$ However, in people aged over 70 years, an eGFR in the range $45-59 \mathrm{~mL} / \mathrm{min} / 1.73 \mathrm{~m}^{2}$, if stable over time and without any other evidence of kidney damage, is unlikely to be associated with CKD related complications. $^{2}$

Table I: Recommended equations for estimation of GFR ${ }^{17,21}$

1. Equation from the Modification of Diet in Renal Disease study

Estimated GFR $\left(\mathrm{mL} / \mathrm{min}\right.$ per $\left.1.73 \mathrm{~m}^{2}\right)$

$=186 \times(\mathrm{S} . \mathrm{Cr} \mathrm{mg} / \mathrm{dL})^{-1.154} \times(\text { age in years })^{-0.203}$

Multiply by 0.742 for women

Multiply by 1.21 for African Americans

2. Cockcroft-Gault equation Estimated creatinine clearance $(\mathrm{mL} / \mathrm{min})$

(140-age in years) $\times$ body weight $(\mathrm{kg})$

$72 \times$ S. $\mathrm{Cr}(\mathrm{mg} / \mathrm{dL})$

Multiply by 0.85 for women 


\section{Stages of CKD}

The NKF classifies CKD into five stages (Table II) based on the GFR and/or presence of kidney damage. ${ }^{7}$ This staging system is widely accepted by various clinical guidelines on the management of chronic kidney disease. . $^{, 8-13}$

Table II: Classification of chronic kidney disease ${ }^{7}$

\begin{tabular}{|c|c|c|}
\hline Stage & GFR $\left(\mathrm{mL} / \mathrm{min}\right.$ per $\left.1.73 \mathrm{~m}^{2}\right)$ & Description \\
\hline 1 & $\geqslant 90$ & $\begin{array}{c}\text { Kidney damage with } \\
\text { normal or } \uparrow \mathrm{GFR}\end{array}$ \\
\hline 2 & $60-89$ & $\begin{array}{c}\text { Kidney damage with } \\
\text { mild } \downarrow \text { GFR }\end{array}$ \\
\hline 3 & $30-59$ & Moderate $\downarrow$ GFR \\
4 & $15-29$ & Severe $\downarrow$ GFR \\
\hline 5 & $<15$ & Kidney failure \\
\hline
\end{tabular}

Advanced chronic kidney disease, kidney failure and end stage renal disease

Stages 4 and 5 are sometimes called advanced CKD. ${ }^{2}$ The NKF guidelines define kidney failure as either 1) GFR less than $15 \mathrm{~mL} / \mathrm{min}$ per $1.73 \mathrm{~m}^{2}$, which is accompanied in most cases by signs and symptoms of uremia, or 2) a need to start RRT. ${ }^{7}$ The dispiriting term ESRD represents a stage of CKD where the accumulation of toxins, fluid, and electrolytes normally excreted by the kidneys results in the uremic syndrome. This syndrome leads to death unless the toxins are removed by RRT, using dialysis or kidney transplantation. 6,22 Denial of therapy means death in days, weeks, or months. ESRD includes patients treated by dialysis or transplantation, irrespective of the level of GFR. ${ }^{7}$

\section{Complications}

The complications of CKD tend to occur at relatively predictable stages of disease as noted in Table III. Stages 1 and 2 CKD are usually not associated with any symptoms arising from the decrement in GFR. However, there may be symptoms from the underlying renal disease itself, such as edema in patients with nephrotic syndrome or signs of hypertension secondary to some forms of glomerulonephritis. If the decline in GFR progresses to stages 3 and 4, clinical and laboratory complications of CKD become more prominent. Virtually all organ systems are affected, but the most evident complications include anemia, decreasing appetite with progressive malnutrition, abnormalities in calcium, phosphorus and mineral-regulating hormones, such as $1,25(\mathrm{OH})_{2} \mathrm{D}_{3}$ (calcitriol) and parathyroid hormone (PTH), and abnormalities in sodium, potassium, water and acid-base homeostasis. $^{6}$

Table III: Complications of CKD by stage and $\mathrm{GFR}^{7,23}$

\begin{tabular}{|c|l|l|l|}
\hline Stage & $\begin{array}{c}\text { GFR } \\
\left(\mathrm{mL} / \mathrm{min} \text { per } 1.73 \mathrm{~m}^{2}\right)\end{array}$ & \multicolumn{1}{|c|}{ Description } & \multicolumn{1}{c|}{ Complications } \\
\hline 1 & $\geqslant 90$ & $\begin{array}{l}\text { Kidney damage with } \\
\text { normal or } \uparrow \mathrm{GFR}\end{array}$ & Patient at risk of CKD \\
\hline 2 & $60-89$ & $\begin{array}{l}\text { Kidney damage with } \\
\text { mild } \downarrow \text { GFR }\end{array}$ & Hypertension \\
\hline 3 & $30-59$ & Moderate $\downarrow$ GFR & $\begin{array}{l}\text { Mild } \uparrow \text { in serum creatinine, mild } \downarrow \text { in serum } \\
\text { calcium, onset of anemia }\end{array}$ \\
\hline 4 & $15-29$ & Severe $\downarrow$ GFR & $\begin{array}{l}\text { Anorexia, moderate anemia, hyperkalemia } \\
\text { hyperphosphatemia, dyslipidemia, neuropathy, } \\
\text { left ventricular hypertrophy }\end{array}$ \\
\hline 5 & $<15$ & Kidney failure & $\begin{array}{l}\text { Uremic symptoms, severe anemia, } \\
\text { malnutrition, secondary hyperparathyroidism, } \\
\text { metabolic acidosis }\end{array}$ \\
\hline
\end{tabular}




\section{Management}

\section{Maintenance of euvolemia (fluid balance)}

It has been suggested to limit sodium intake for its effects on both fluid balance and blood pressure. ${ }^{24,25}$ In advanced CKD, the kidney is unable to adapt to large changes in sodium intake. Intake $>3-4 \mathrm{~g}$ /day can lead to hypertension and volume overload, whereas intake of $<1 \mathrm{~g} /$ day can lead to volume depletion and hypotension. A goal of $2 \mathrm{~g}$ /day of sodium is reasonable for most patients. A daily intake of $2 \mathrm{~L}$ of fluid maintains water balance. ${ }^{25} \mathrm{But}$ overzealous salt restriction or diuretic use can lead to extracellular fluid volume depletion and precipitate a further decline in GFR. Patients with salt-losing nephropathy may require a sodium-rich diet or salt supplementation. ${ }^{6,24}$

\section{Hyperkalemia}

Hyperkalemia often responds to dietary restriction of potassium, avoidance of potassium supplements as well as potassium-retaining medications [especially spironolactone, angiotensin-converting enzyme (ACE) inhibitors/angiotensin-receptor blockers (ARBs)], or the use of kaliuretic diuretics such as metolazone. Metolazone promotes urinary potassium excretion, while a potassium-binding resin, such as calcium resonium or sodium polystyrene, promotes potassium loss through the gastro-intestinal tract and may reduce the incidence of hyperkalemia in CKD patients. ${ }^{25}$

a) Acute hyperkalemia: calcium chloride or gluconate intravenously, insulin administration with glucose intravenously, bicarbonate intravenously, and potassium-binding resin orally or per rectum, cardiac monitoring. ${ }^{25}$ Intractable hyperkalemia is an indication (although uncommon) to consider institution of dialysis in a CKD patient. ${ }^{25}$

b) Chronic hyperkalemia: dietary potassium restriction and sodium polystyrene, 15-30 g once daily orally in juice or sorbitol. ${ }^{25}$

\section{Acidemia}

It has been suggested that in presence of acidemia oral alkali therapy can slow CKD progression. ${ }^{25}$ The plasma bicarbonate should be maintained $>22$ $\mathrm{mmol} / \mathrm{L}$ by giving sodium bicarbonate supplements (starting dose of $1 \mathrm{~g}$ 8-hourly, increasing as required). 6,24 It must be remembered that the increased sodium intake may induce hypertension or edema. $^{24}$

\section{Hypertension}

Hypertension is commonly associated with CKD in more than $75 \%$ of patients. ${ }^{26}$ Various target blood pressures have been suggested, for example, 130/80 $\mathrm{mm} \mathrm{Hg}$ or less for CKD alone, and lowered to $125 / 75 \mathrm{~mm} \mathrm{Hg}$ for those with proteinuria $>1$ g/day. $6,7,24,27,28$

In CKD if hypertension is associated with significant proteinuria $(0.5 \mathrm{~g} / 24 \mathrm{~h}$ or more $)$, ACE inhibitors/ ARBs should be offered because of their unique ability to decrease proteinuria preferentially by lowering intra-glomerular pressure. ${ }^{2,27}$ In hypertension with urinary protein excretion $<0.5 \mathrm{~g} / 24 \mathrm{~h}$, ACE inhibitors, ARBs, long-acting calcium channel blockers, thiazide diuretics or beta-blockers can be used. $^{2}$

When ACE inhibitor/ARB therapy is started, some patients with CKD may have an initial decrease in GFR, a mild increase in the serum creatinine concentration, and a mild increase in the potassium level. ${ }^{29}$ Therefore, in people with CKD, serum creatinine and potassium levels should be measured and the GFR should be estimated before starting ACE inhibitor/ARB therapy. These measurements should be repeated between $7^{\text {th }}$ and $14^{\text {th }}$ day after starting ACE inhibitor/ARB therapy and after each dose increase. ${ }^{2}$ ACE inhibitor/ARB therapy should not normally be started if the pretreatment serum potassium concentration is significantly above the normal reference range. Often the concomitant use of a kaliuretic diuretic can improve potassium excretion in addition to improving blood pressure control. 2,6

\section{Proteinuria}

Increased intraglomerular filtration pressures develop as a response to loss of nephron number from CKD as well as from systemic hypertension. Control of systemic and glomerular hypertension is important in slowing the progression of CKD. ACE inhibitors and ARBs inhibit the angiotensin-induced vasoconstriction of the efferent arterioles of the glomerular microcirculation. This inhibition leads to a reduction in both intraglomerular filtration pressure and proteinuria. ACE inhibitors or ARBs should be 
offered to non-diabetic people with CKD with urinary protein excretion $0.5 \mathrm{~g} / 24 \mathrm{~h}$ or more..$^{2,27}$

\section{Anemia}

a) Erythropoiesis-stimulating agents (ESAs) are FDA-approved in CKD for a goal hemoglobin $(\mathrm{Hb})$ of $10-11 \mathrm{~g} / \mathrm{dL}$ if no other treatable causes for anemia are present. ${ }^{25}$ Other various target $\mathrm{Hb}$ suggested by different clinical guidelines are $10-12 \mathrm{~g} / \mathrm{dL}^{2,24}$, 11-12 g/dL 7,27 and $10-11.5 \mathrm{~g} / \mathrm{dL}^{6}{ }^{6}$ ESAs (e.g., recombinant erythropoietin [epoetin] and darbepoetin) are effective in correcting anemia of CKD. The starting dose of epoetin is 50 units $/ \mathrm{kg}$ (3000-4000 units/dose) once or twice a week. Darbepoetin is started at $0.45 \mathrm{mcg} / \mathrm{kg}$ and can be administered every 2-4 weeks. ${ }^{25}$ ESAs are less effective in the presence of iron deficiency, active inflammation, malignancy, intercurrent illness, or in patients with aluminium overload, which may occur in dialysis. ${ }^{24}$ The use of ESAs for the treatment of anemia in patients with CKD is associated with potential adverse outcomes, including increased blood pressure, thrombotic complications (like stroke) and possibly other CVD events. ${ }^{25,27}$

b) Iron therapy is an important component of anemia management. Iron supplementation is usually essential to ensure an optimal response to ESAs in patients with CKD because the demand for iron by the marrow frequently exceeds the amount of iron that is immediately available for erythropoiesis (measured by percent transferrin saturation), as well as the amount in iron stores (measured by serum ferritin). In CKD, a serum ferritin $<100 \mathrm{ng} / \mathrm{mL}$ or iron saturation $<20 \%$ is suggestive of iron deficiency. ${ }^{25}$ Iron stores should be repleted prior to the initiation of ESAs. For the CKD patient not yet on dialysis, oral iron supplementation should be attempted. If there is GI intolerance, the patient may have to undergo intravenous (IV) iron infusion. ${ }^{6}$ People receiving ESA maintenance therapy should be given iron supplements to keep their serum ferritin levels between 200 and $500 \mathrm{ng} / \mathrm{mL}^{2}$ Iron therapy should probably be withheld if the serum ferritin is $>500 \mathrm{ng} / \mathrm{mL}$, even if the iron saturation is $<20 \%$. ${ }^{25}$ Oral therapy with ferrous sulfate, gluconate, or fumarate, $325 \mathrm{mg}$ once to three times daily, is the initial therapy in CKD. ${ }^{25}$ For patients on hemodialysis, IV iron can be administered during dialysis. In addition to iron, an adequate supply of other major substrates and cofactors for red cell production must be ensured, including vitamin $\mathrm{B}_{12}$ and folate. ${ }^{25}$

c) Red cell transfusion to treat anemia in CKD becomes necessary sometimes. In people with anemia of CKD in whom kidney transplant is a treatment option, red cell transfusions should be avoided if possible, to minimize the risk of alloimmunization related to their use. ${ }^{2}$ It has been suggested by investigators in one study that the decision to transfuse a CKD patient with non-acute anemia should not be based on any arbitrary $\mathrm{Hb}$ threshold only, but should be determined also by the occurrence of symptoms caused by anemia. In particular, they suggest considering transfusion at $\mathrm{Hb}$ values $\leqslant 7 \mathrm{~g} / \mathrm{dL}$ or at $\mathrm{Hb}$ values $\leqslant 8 \mathrm{~g} / \mathrm{dL}$ in postoperative surgical patients. ${ }^{30}$

\section{Chronic kidney disease-mineral bone disorders (CKD-MBD)}

In $\mathrm{CRF}$, hypocalcemia results from inadequate production of 1, 25-dihydroxycholecalciferol (calcitriol) by the kidneys needed for calcium retention and resorption. Hyperphosphatemia is a consequence of reduced urinary phosphate excretion due to declining GFR. Phosphorus complexes with calcium, deposits in soft tissues and causes soft tissue calcification. Hypocalcemia, decreased calcitriol and hyperphosphatemia stimulates the parathyroid glands for secretion of excessive parathyroid hormone $(\mathrm{PTH})$ resulting in secondary hyperparathyroidism. This typical pattern of hyperphosphatemia, hypocalcemia, hypovitaminosis $\mathrm{D}$, and secondary hyperparathyroidism is seen as early as CKD stage 3.25 Excessive PTH helps to maintain calcium levels mainly by bone resorption and causes osteitis fibrosa and other disturbances like osteomalacia, osteoporosis and osteosclerosis. ${ }^{24}$ These disturbances have traditionally been termed renal osteodystrophy. ${ }^{31}$ Disturbances in mineral metabolism also results in vascular calcification due to deposition of calcium phosphate complex, resulting in vascular rigidity and occlusion which may be partly responsible for the accelerated CVD and excess mortality seen in the CKD population. As the disorder is not confined to the skeleton, in 2005, the Kidney Disease: Improving Global Outcomes (KDIGO) clinical practice proposed replacing the 
term renal osteodystrophy by CKD-MBD. ${ }^{32}$ CKDMBD is manifested by an abnormality of any one or a combination of the following disorderslaboratory-abnormalities of calcium, phosphorus, PTH, or vitamin D metabolism; bone-changes in bone turnover, mineralization, volume, or strength and calcification in the soft-tissue and the arterial vessels. ${ }^{31,32}$

a) Control of hyperphosphatemia is the first step in the treatment of CKD-MBD. ${ }^{25}$ This involves dietary phosphorus restriction initially, followed by the administration of oral phosphorus binders if targets are not achieved. Examples of foods with high phosphate content are milk, cheese, eggs, nuts, peas, beans, colas, and dairy products. ${ }^{24}$ Oral phosphorus binders, such as calcium carbonate/gluconate (500 $\mathrm{mg} /$ tablet, maximum $3 \mathrm{gm}$ daily) or calcium acetate (667 mg/capsule, maximum $1500 \mathrm{mg}$ daily) block absorption of dietary phosphorus in the gut and are given thrice daily with meals. These should be titrated to a serum phosphorus of $<4.5 \mathrm{mg} / \mathrm{dL}$ in stage 3-4 CKD and $<5.5 \mathrm{mg} / \mathrm{dL}$ in ESRD. A major side-effect of calcium-based phosphate binders is hypercalcemia. Therefore doses should be decreased or stopped if serum calcium rises above $10 \mathrm{mg} / \mathrm{dL} .{ }^{25}$ Phosphorus-binding agents that do not contain calcium are aluminium hydroxide, sevelamer and lanthanum. Sevelamer, 800-3200 mg and lanthanum carbonate, $500-1000 \mathrm{mg}$ are given at the beginning of meals and may be combined with calciumcontaining binders. 6,25 Aluminium exposure should be avoided. High levels of aluminium may be present in impure dialysate water. ${ }^{25}$ Aluminium hydroxide is a highly effective phosphorus binder, but can cause osteomalacia and neurologic complications when used long-term. It can be used in the acute setting for serum phosphorus $>7 \mathrm{mg} / \mathrm{dL}$ or for short periods (e.g., 3 weeks) in CKD patients; however, long-term use should be avoided. ${ }^{25}$

b) Secondary hyperparathyroidism can be prevented by restricting dietary phosphate intake, using a calcium-based phosphate binder, and administering calcitriol. ${ }^{33}$ Best practice is to maintain normal calcium, phosphate, and 1, 25-dihydroxycholecalciferol. Once serum phosphorus levels are controlled, active vitamin D (calcitriol) or active vitamin D analogues are recommended to treat secondary hyperparathyroidism (if PTH more than twice normal) or hypocalcaemia in stage $3-5 \mathrm{CKD} .^{24,25}$ Typical calcitriol dosing is 0.25 or $0.5 \mathrm{mcg}$ orally daily or every other day. ${ }^{25}$ Serum $25-\mathrm{OH}$ vitamin D levels should be measured and brought to normal by vitamin D supplementation. ${ }^{34}$ When vitamin D supplementation is indicated in people with CKD, certain clinical guidelines recommend cholecalciferol or ergocalciferol to people with stage 1, 2, or $3 \mathrm{CKD}$ and calcitriol or 1-alpha-hydroxycholecalciferol (alfacalcidol) to people with stage 4 or $5 \mathrm{CKD} .{ }^{35}$ The routine measurement of serum calcium, phosphate, and PTH levels in people with stage 1, 2, 3 CKD is not recommended, but needs measurement in people with stage 4 or $5 \mathrm{CKD}{ }^{35}$ Calcitriol therapy may result in hypercalcemia and/or hyperphosphatemia through increased GI absorption of these minerals. The dose of calcitriol should be decreased or stopped if hypercalcemia or hyperphosphatemia occurs. ${ }^{2}$ Calcitriol exerts a direct suppressive effect on PTH secretion and also indirectly suppresses PTH secretion by raising the concentration of ionized calcium. Certain analogues of calcitriol (e.g., paricalcitol) are available that suppress PTH secretion with less attendant hypercalcemia. ${ }^{6}$ Calcimimetic agents (e.g., cinacalcet) which enhance the sensitivity of the parathyroid cell to the suppressive effect of calcium have been developed recently. This class of drug produces a dose-dependent reduction in PTH production and plasma calcium concentration. ${ }^{6,35}$ Cinacalcet, 30-90 mg orally once a day, can be used if elevated serum phosphorus or calcium levels prohibit the use of vitamin D analogues. ${ }^{25}$

In 2009 KDIGO clinical practice released guidelines on the management of CKD-MBD which suggests that, if the PTH levels fall below two times the upper limit of normal for the assay, calcitriol or calcimimetics be reduced or stopped. ${ }^{6,35}$

c) Tertiary hyperparathyroidism: Even with appropriate medical therapy, some patients continue to have refractory hyperparathyroidism because of parathyroid gland hyperplasia. In patients with severe hyperparathyroidism who fail to respond to medical/pharmacological therapy, the KDIGO guideline suggests parathyroidectomy. ${ }^{35}$ 


\section{Dyslipidemia}

Dyslipidemia is a common complication of progressive CKD and a primary risk factor for CVD. The goals are an LDL cholesterol level below 100 $\mathrm{mg}$ per dL (2.60 mmol per L) and a triglyceride level below $200 \mathrm{mg}$ per dL (2.26 mmol per L). ${ }^{36}$ Statins should be offered to people with CKD for the secondary prevention of CVD irrespective of baseline lipid values. ${ }^{2}$ Fibrates are known to decrease triglyceride levels, but they may increase the risk for rhabdomyolysis in patients with CKD. ${ }^{27}$

\section{Antiplatelet drugs}

Antiplatelet drugs should be offered to people with $\mathrm{CKD}$ for the secondary prevention of CVD. ${ }^{2}$

\section{Hyperuricemia}

There is also theoretic value in lowering uric acid levels in CKD patients with concomitant hyperuricemia, but clinical data regarding benefit are still lacking. 25

\section{Nutrition}

Counseling on adequate and appropriate nutrition should be provided at each office visit. Dietary advice should be offered to people with progressive CKD concerning protein, calorie, salt, potassium and phosphate intake, when indicated. ${ }^{2}$

a) Protein intake: The effect of dietary protein restriction on kidney disease is the subject of debate. There is a lack of convincing evidence that the longterm restriction of protein intake $(<0.70 \mathrm{~g} / \mathrm{kg} /$ day $)$ delays the progression of CKD. ${ }^{6,27}$ Nonetheless, restriction of dietary protein intake has been recommended for CKD patients. For non-diabetic and diabetic patients with CKD stage 4, two systematic reviews and one meta-analysis suggested that, in comparison to other treatments, there was, at most, a modest benefit associated with restricting protein leading to a delay in CKD progression. ${ }^{37,38}$ High protein intakes are associated with high phosphate intakes as foods that contain protein also tend to contain phosphate. It would appear prudent to avoid high protein intakes in stage 4 CKD patients when hyperphosphatemia is prevalent. The ADA recommends reduction of protein intake to $0.8-1.0$ $\mathrm{g} / \mathrm{kg}$ body wt/day in individuals with diabetes and the earlier stages of CKD and to $0.8 \mathrm{~g} / \mathrm{kg}$ body $\mathrm{wt} /$ day in the later stages of CKD that may improve renal function. ${ }^{39}$ Current recommendations from the NKF K/DOQI and other studies suggest a protein intake of 0.8 to $1.0 \mathrm{~g} / \mathrm{kg} / \mathrm{day}$ in patients with CKD. ${ }^{7,40-42}$ It is further advised that at least $50 \%$ of the protein intake be of high biologic value. ${ }^{6}$ Benefits of protein restriction in slowing decline of GFR must be weighed against the risk of malnutrition and cachexia upon the initiation of dialysis. $^{25}$

b) Energy intake: An adequate nutrition with daily caloric intake of 30 to $35 \mathrm{kcal}$ per $\mathrm{kg} /$ day in patients with CKD has been recommended. 6,7

c) Salt and water restriction: A goal of 2 g/day of sodium intake is reasonable for nondialysis patient approaching ESRD; a daily intake of $2 \mathrm{~L}$ of fluid maintains water balance. ${ }^{25}$ Patients with salt-losing nephropathy may require a sodium-rich diet or salt supplementation. ${ }^{6}$

d) Potassium restriction: A goal of $<50-60 \mathrm{mEq} /$ day intake of potassium is adequate. Restriction is needed once the GFR has fallen below 10-20 $\mathrm{mL} / \mathrm{min} / 1.73 \mathrm{~m}^{2}$, or earlier if the patient is hyperkalemic. $^{25}$

e) Phosphorus restriction: Phosphorus needs to be restricted to $800-1000 \mathrm{mg} /$ day. Foods rich in phosphorus such as cola beverages, eggs, dairy products, nuts, beans, and meat should be limited, although care must be taken to avoid protein malnutrition. ${ }^{25}$ Phosphorus-containing medicines, particularly cathartics should be avoided. ${ }^{25}$

f) Magnesium-containing medications, such as laxatives and antacids are contraindicated. Many drugs are excreted by the kidney; dosages should be adjusted for GFR. ${ }^{25}$

\section{Lifestyle advice}

Most patients with CKD will die of events related to CVD before ESRD develops. ${ }^{43}$ Therefore, an important focus of care for patients with CKD includes management of cardiovascular risk factors. People with CKD should be encouraged at each office visit to take regular exercise, achieve a healthy weight and stop smoking completely. Smoking is a strong risk factor for cardiovascular mortality in patients with CKD. ${ }^{44}$ It is also strongly associated 
with the progression of nephropathy. ${ }^{44}$ A target weight of BMI $<23$ should be ideal. ${ }^{2}$

\section{Treatment of underlying cause for preventing progression of CKD}

Treatment of the underlying cause of CKD is vital. These include optimized glucose control in diabetes mellitus, immunomodulatory agents for glomerulonephritis, and emerging specific therapies to retard cytogenesis in polycystic kidney disease. ${ }^{6,25}$

\section{Diabetes}

Control of diabetes should be aggressive in early CKD; excellent glycemic control reduces the risk of kidney disease and its progression. ${ }^{25}$ The American Diabetes Association (ADA) and Canadian guidelines recommend that plasma values for preprandial glucose be kept in the $5.0-7.2 \mathrm{mmol} / \mathrm{L}$ (90-130 mg/dL) range and hemoglobin $A_{1 C}$ should be $<7 \%$ to prevent progression of CKD in patients with DM. ${ }^{27,45}$

The half-life of insulin is prolonged in CKD due to reduced tubular metabolism of insulin; patients on insulin therapy may need progressive reduction in dose as their renal function worsens. Risk of hypoglycemia increases in advanced CKD, and glycemic targets may need to be relaxed to avoid this dangerous complication. ${ }^{24}$ Many hypoglycemic agents such as metformin require dose reduction in renal failure, and some are contraindicated when the GFR is $<50 \mathrm{~mL} / \mathrm{min} / 1.73 \mathrm{~m}^{2} .{ }^{25}$ Metformin can cause lactic acidosis; and the thiazolidinediones (e.g., pioglitazone) may increase renal salt and water absorption and aggravate volume-overload states, and contribute to adverse cardiovascular events. ${ }^{6}$

ACE inhibitors or ARBs should be used in individuals with microalbuminuria as well as with macroalbuminuria irrespective of presence of hypertension in diabetes. ${ }^{9}$ ACE inhibitors and ARBs are effective at reducing proteinuria, slowing the decline in GFR and retarding the progression of diabetic kidney disease. ${ }^{2}$

The definition of hypertension in DM or diabetic kidney disease (DKD) is blood pressure of $130 / 80$ $\mathrm{mm} \mathrm{Hg}$ or greater. ${ }^{46}$ In patients with diabetes having kidney disease and hypertension, treatment with $\mathrm{ACE}$ inhibitors or ARBs has been recommended by various guidelines to prevent progression of CKD. ${ }^{2,8-13}$

\section{Initiation of renal replacement therapy (RRT)}

Although the overall objectives of the guidelines and recommendations are to delay progression of both CKD and its complications, kidney function may continue to deteriorate in a proportion of patients. Ultimately, patients may develop uremia and kidney failure and the need of RRT (either dialysis or transplantation) to extend their life. Patients with kidney failure should be evaluated for kidney transplantation. A kidney transplant from a live donor should be promoted as the first choice for eligible patients who require RRT. Outcomes with deceased donor kidneys are also significantly better than with dialysis. For patients with progressive CKD with plans for hemodialysis, making plans for vascular access is an important component of their care in preparation for ESRD. Acute uremia or uremia resulting from progressive disease is an indication for immediate dialysis.

\section{Key clinical recommendations}

Early detection and management of CKD can prevent kidney disease progression and decrease its complications. All patients should be assessed to determine their susceptibility to or development of CKD. The clinical evaluation should include analysis for risk factors, markers of CKD (e.g. assessment for persistent albuminuria), GFR estimation, and a treatment plan to slow the progression. Key clinical recommendations for treatment, prevention and delaying the progression of CKD and its complications are:

a) According to the evidence, ACE inhibitors/ARBs have been shown to reduce proteinuria and the occurrence of kidney failure. $2,29,47-50$

b) Evidence suggests that ACE inhibitors are more effective than other antihypertensive drugs in preventing the progression of kidney disease in diabetic and nondiabetic patients. ${ }^{51-54}$

c) The seventh report of the Joint National Committee on Prevention, Detection, Evaluation, and Treatment of High Blood Pressure recommends a target blood pressure of less than 130/80 $\mathrm{mm} \mathrm{Hg}$ in patients with chronic kidney disease. ${ }^{28}$ 
d) To prevent progression of nephropathy in patients with DM, the ADA recommends glycemic control, with the goal being a $\mathrm{HbA} 1 \mathrm{C}<7$ percent. ${ }^{45}$

e) The most recent guidelines from the NKF recommend treating dyslipidemia aggressively in patients with CKD. The goals are a LDL cholesterol level below $100 \mathrm{mg}$ per $\mathrm{dL}(2.60 \mathrm{mmol} / \mathrm{L})$ and a triglyceride level below $200 \mathrm{mg}$ per dL (2.26 $\mathrm{mmol} / \mathrm{L}){ }^{36}$

f) Anemia in CKD responds to ESAs. Iron therapy is an important component of anemia management in CKD. The target goal of $\mathrm{Hb}$ is $10-11 \mathrm{~g} / \mathrm{dL}{ }^{25} \mathrm{In}$ CKD patients, where kidney transplant is a treatment option, red cell transfusions should be avoided if possible. $^{2}$

g) Epidemiologic studies in humans show an association between elevated phosphorus levels and increased risk of cardiovascular mortality in early CKD through ESRD. ${ }^{25}$ Control of hyperphosphatemia is the first step in the treatment of CKDMBD. ${ }^{25}$ While using calcium-based phosphorus binders, hypercalcemia must be avoided to prevent aggravation of soft tissue and vascular calcification leading to increased cardiovascular morbidity and mortality.

h) Protein restriction may be effective in slowing the progression of $\mathrm{CKD}$, especially proteinuric and diabetic renal diseases. Benefits of protein restriction in slowing decline of GFR must be weighed against the risk of malnutrition and cachexia upon the initiation of dialysis. ${ }^{25}$

\section{Conclusion}

The incidence of CKD is increasing worldwide and unfortunately, CKD is often undetected and undertreated because of its insidious onset, variable progression, and length of time to overt kidney failure. Its natural course is an eventual decline in the GFR, leading to kidney failure and the need for RRT. The goal of therapy is to detect CKD early to delay its progression, thereby reducing associated complications and adverse outcomes of kidney disease. Patients with one or more risk factors should have their GFR estimated and be assessed for persistent albuminuria. Evidence supports that achieving optimal glucose control, blood pressure, and reduction in albuminuria slows the progression of $\mathrm{CKD}{ }^{7,10,28,55-59} \mathrm{ACE}$ inhibitors are more effective than other antihypertensive drugs in preventing the progression of kidney disease in diabetic and nondiabetic patients. Other interventions studied to reduce progression include correction of anemia, treatment of CKD-MBD, dietary protein restriction, and lipid-lowering therapy.

\section{References}

1. Excerpts from the United States renal data system's 2000 annual data report: atlas of end-stage renal disease in the United States. Am J Kidney Dis 2000; 36(6 Suppl 2): S1-S137.

2. NICE clinical guidelines. Chronic kidney disease. Early identification and management of chronic kidney disease in adults in primary and secondary care CG73. September 2008. Available at: http://publications. nice.org.uk/chronic-kidney-disease-cg73. Accessed July 2013.

3. Rashid HU. Bangladesh renal registry report 1986-1996. Bang Renal J. 2002; 21(1): 25-28.

4. Sakhuja V, Sud K. End stage renal disease in India and Pakistan: burden of disease and management issues. Kidney Int Suppl. 2002; 83: S115-S118.

5. Ahmed ST, Rahim MA, Ali MZ, Iqbal MM. Prevalence of primary renal disease among patients on maintenance hemodialysis: a hospital based study. KYAMC Journal 2012; 2(2): 182-186.

6. Bargman JM, Skorecki K. Chronic kidney disease. In: Longo DL, Fauci AS, Kasper DL, Hauser SL, Jameson JL, Loscalzo J (eds). Harrison's principles of internal medicine. 18th edn. New York: McGraw-Hill, 2012: 2308-2321.

7. National Kidney Foundation. K/DOQI clinical practice guidelines for chronic kidney disease: evaluation, classification, and stratification. Am J Kidney Dis 2002; 39(2 Suppl 1): S1-S266.

8. UK CKD guidelines consultation draft 9th December 2005. Available at: http://www.kidney.org.uk/main/ guidelines/UK_CKD_guidelines_consultation_draft.pdf. Accessed May 2013.

9. International Diabetes Federation, 2012. Clinical guidelines task force global guideline for type 2 diabetes. Available at: http://www.societate-diabet.ro/ pdf/global-guideline-for-type-2-diabetes-IDF-2012.pdf. Accessed June 2013

10. American Diabetes Association. Position statement: nephropathy in diabetes. Diabetes Care 2004; 27: S79-S83.

11. Canadian Diabetes Association Clinical Practice Guidelines Expert Committee. Canadian Diabetes 
Association 2008 clinical practice guidelines for the prevention and management of diabetes in Canada. Can J Diabetes 2008; 32: S95-S98.

12. Scottish Intercollegiate Guidelines Network. Management of diabetes. A national clinical guideline. March 2010. Available at: http://www.sign.ac.uk/pdf/sign116.pdf. Accessed March 2013.

13. Chadban S, Howell M, Twigg S, Thomas M, Jerums G, Alan $\mathrm{C}$ et al. National evidence based guideline for diagnosis, prevention and management of chronic kidney disease in type 2 diabetes. Canberra: Diabetes Australia and the NHMRC; 2009. Available at: http://www.nhmrc.gov.au/_files_nhmrc/publications/atta chments/di18-diabetes-kidney-disease.pdf. Accessed April 2013.

14. Snively SC, Gutierrez C. Chronic kidney disease: prevention and treatment of common complications. Am Fam Physician 2004; 70(10): 1921-1928.

15. Cumming A, Payne S. The renal system. In: Doglas G, Nicol F, Robertson C (eds). Macleod's clinical examination. $12^{\text {th }}$ edn. Edinburgh: Churchill Livingstone Elsevier, 2009: 223-224.

16. Levey AS, Coresh J, Balk E, Kausz AT, Levin A, Steffes MW et al. National Kidney Foundation practice guidelines for chronic kidney disease: evaluation, classification, and stratification. Ann Intern Med 2003; 139: $137-147$.

17. Levey AS, Bosch JP, Lewis JB, Greene T, Rogers N, Roth D. A more accurate method to estimate glomerular filtration rate from serum creatinine: a new prediction equation. Modification of diet in renal disease study group. Ann Intern Med 1999; 130: 461-470.

18. Davies DF, Shock NW. Age changes in glomerular filtration rate, effective renal plasma flow, and tubular excretory capacity in adult males. J Clin Invest 1950; 29: 496-507.

19. Lindeman RD, Tobin J, Shock NW. Longitudinal studies on the rate of decline in renal function with age. J Am Geriatr Soc 1985; 33: 278-285.

20. Rowe JW, Andres R, Tobin JD, Norris AH, Shock NW. The effect of age on creatinine clearance in men: a cross-sectional and longitudinal study. J Gerontol 1976; 31: $155-163$.

21. Cockcroft DW, Gault MH. Prediction of creatinine clearance from serum creatinine. Nephron 1976; 16: 31-41.

22. Mendelssohn DC. Policy statement - principles of endstage renal disease care. Annals RCPSC 1997; 30(5): 271-273.

23. Parmar M. Chronic renal disease. BMJ 2002; 325: 85-90.
24. Goddard J, Turner AN, Stewart LH. Kidney and urinary tract disease. In: Colledge NR, Walker BR, Ralston SH (eds). Davidson's principle and practice of medicine. $21^{\mathrm{St}}$ edn. Edinburgh: Churchill Livingstone Elsevier, 2010: 480-496.

25. Watnick S, Dirkx T. Kidney disease. In: Papadakis MA, McPhee SJ, Rabow MW (eds). Current medical diagnosis \& treatment 2013. New York: McGraw-Hill, 2013: Chapter 22. Avalable: at http://www. accessmedicine.com/content.aspx?aID $=11374$. Accessed August 2013

26. Culleton B. Introduction to the Canadian clinical practice guidelines. J Am Soc Nephrol 2006; 17: S1-S3.

27. Levin A, Hemmelgarn B, Culleton B, Tobe S, McFarlane P, Ruzicka $M$ et al. Guidelines for the management of chronic kidney disease. CMAJ 2008; 179(11): 1154-1162.

28. Chobanian AV, Bakris GL, Black HR, Cushman WC, Green LA, Izzo JL Jr et al. The seventh report of the Joint National Committee on prevention, detection, evaluation, and treatment of high blood pressure. JAMA. 2003; 289: 2460-2472.

29. Levey AS. Clinical practice. Nondiabetic kidney disease. N Engl J Med 2002; 347: 1505-1511.

30. Drüeke TB, Locatelli F, Clyne N, Eckardt KU, Macdougall IC, Tsakiris D et al. CREATE investigators. Normalization of hemoglobin level in patients with chronic kidney disease and anemia. N Engl J Med 2006; 355: 2071-2084.

31. Moe SM, Drüeke T, Lameire N, Eknoyan G. Chronic kidney disease-mineral-bone disorder: a new paradigm. Adv Chronic Kidney Dis 2007; 14(1): 3-12.

32. Suchowierska E, Mysliwiec M. Mineral and bone disturbances associated with chronic kidney disease [Review]. Pol Merkur Lekarski 2010; 28(164): 138-143. PMID: 20369744.

33. Ho LT, Sprague SM. Renal osteodystrophy in chronic renal failure. Semin Nephrol 2002; 22: 488-493.

34. Slatopolsky E, Berkoben M, Kelber J, Brown A, Delmez J. Effects of calcitriol and non-calcemic vitamin D analogs on secondary hyperparathyroidism. Kidney Int Suppl 1992; 38: S43-S49.

35. Moe SM, Drüeke TB, Block GA, Cannata-Andía JB, Elder GJ, Fukagawa $\mathrm{M}$ et al. KDIGO clinical practice guideline for the diagnosis, evaluation, prevention, and treatment of chronic kidney disease-mineral and bone disorder (CKDMBD). Kidney Int Suppl 2009; 113: S1-S130.

36. National Kidney Foundation. Kidney Disease Outcomes Quality Initiative. K/DOQI clinical practice guidelines for managing dyslipidemias in chronic kidney disease. 2003. Available at: http://www.kidney.org/professionals/ kdoqi/guidelines_lipids/index.htm. Accessed July 2013. 
37. Fouque D, Wang P, Laville M, Boissel JP. Low protein diets for chronic kidney disease in nondiabetic adults (Cochrane review). In: The Cochrane Database Syst Rev. 2009; Issue 3. DOI: 10.1002/14651858.CD001892.pub3.

38. Robertson L, Waugh N, Robertson A. Protein restriction for diabetic renal disease (Cochrane review). In: The Cochrane Database Syst Rev. 2007; Issue 4. CD002181.

39. American Diabetes Association. Standards of medical care in diabetes. Diabetes Care 2013; 36(Suppl 1): S11-S66.

40. Klahr S, Levey AS, Beck GJ, Caggiula AW, Hunsicker L, Kusek JW et al. The effects of dietary protein restriction and blood-pressure control on the progression of chronic renal disease. Modification of Diet in Renal Disease Study Group. N Engl J Med 1994; 330: 877-884.

41. Fouque D, Laville M, Boissel JP. Low protein diets for chronic kidney disease in nondiabetic adults. Cochrane Database Syst Rev 2006; 2: CD001892.

42. Kasiske BL, Lakatua JD, Ma JZ, Louis TA. A metaanalysis of the effects of dietary protein restriction on the rate of decline in renal function. Am J Kidney Dis 1998; 31: 954-961.

43. Keith DS, Nichols GA, Gullion CM, Brown JB, Smith DH. Longitudinal follow-up and outcomes among a population with chronic kidney disease in a large managed care organization. Arch Intern Med 2004; 164: 659-663.

44. Orth SR, Stockmann A, Conradt C, Ritz E, Ferro M, Kreusser $\mathrm{W}$ et al. Smoking as a risk factor for end-stage renal failure in men with primary renal disease. Kidney Int 1998; 54: 926-931.

45. American Diabetes Association. Standards of medical care for patients with diabetes mellitus. Diabetes Care 2003; 26(Suppl 1): S33-S50.

46. National Kidney Foundation. K/DOQI Clinical practice guidelines and clinical practice recommendations for diabetes and chronic kidney disease. Am J Kidney Dis 2007; 49 (2 Suppl 2): S1-S179.

47. Mogensen CE, Neldam S, Tikkanen I, Oren S, Viskoper $\mathrm{R}$, Watts RW et al. Randomised controlled trial of dual blockade of the renin-angiotensin system in patients with hypertension, microalbuminuria, and non-insulin dependent diabetes: the Candesartan and Lisinopril Microalbuminuria (CALM) study. BMJ 2000; 321: 1440-1444.

48. Siebenhofer A, Plank J, Horvath K, Berghold A, Sutton AJ, Sommer R et al. Angiotensin receptor blockers as anti-hypertensive treatment for patients with diabetes mellitus; meta-analysis of controlled double-blind randomized trials. Diabet Med 2004; 21: 18-25.
49. Praga M, Andrade CF, Luno J, Arias M, Poveda R, Mora $\mathrm{J}$ et al. Antiproteinuric efficacy of losartan in comparison with amlodipine in non-diabetic proteinuric renal diseases: a double-blind, randomized clinical trial. Nephrol Dial Transplant 2003; 18: 1806-1813.

50. Brenner BM, Cooper M, de Zeeuw D, Keane WF, Mitch WE, Parving $\mathrm{HH}$ et al. Effects of losartan on renal and cardiovascular outcomes in patients with type 2 diabetes and nephropathy. N Engl J Med 2001; 345: 861-869.

51. Kasiske BL, Kalil RS, Ma JZ, Liao M, Keane WF. Effect of antihypertensive therapy on the kidney in patients with diabetes: a meta-regression analysis. Ann Intern Med 1993; 118: 129-138.

52. Wright JT, Bakris G, Greene T, Agodoa LY, Appel LJ, Charleston $\mathrm{J}$ et al. Effect of blood pressure lowering and antihypertensive drug class on progression of hypertensive kidney disease: results from the AASK trial. JAMA 2002; 288: 2421-2431.

53. Randomised placebo-controlled trial of effect of ramipril on decline in glomerular filtration rate and risk of terminal renal failure in proteinuric, non-diabetic nephropathy. The GISEN Group (Gruppo Italiano di Studi Epidemiolgici in Nefrologia). Lancet 1997; 349: 1857-1863.

54. Ruggenenti P, Perna A, Gherardi G, Gaspari F, Benini R, Remuzzi $G$ et al. Renal function and requirement for dialysis in chronic nephropathy patients on long-term ramipril: REIN follow-up trial. Gruppo Italiano di Studi Epidemiologici in Nefrologia (GISEN). Ramipril Efficacy in Nephropathy. Lancet 1998; 352: 1252-1256.

55. K/DOQI clinical practice guidelines on hypertension and antihypertensive agents in chronic kidney disease. Am J Kidney Dis 2004; 39: S11-S68.

56. Diabetes Control and Complications Trial (DCCT) Research Group. The effect of intensive treatment of diabetes on the development and progression of longterm complications in insulin-dependent diabetes mellitus. N Engl J Med 1993; 329: 977-986.

57. UK Prospective Diabetes Study Group. Intensive blood glucose control with sulphonylureas or insulin compared with conventional treatment and risk of complications in patients with type 2 diabetes (UKPDS 33). Lancet 1998; 352: 837-853.

58. American Diabetes Association. Position statement: hypertension management in adults with diabetes. Diabetes Care 2004; 27: S65-S67.

59. Manley HJ. Role of angiotensin-converting-enzyme inhibition in patients with renal disease. Am J HealthSyst Pharm 2000; 57(Suppl 1): S12-S18. 